Science in Latin America 
THIS PAGE INTENTIONALLY LEFT BLANK 


\section{Science in Latin America}

\section{A History}

EDITED BY JUAN JOSÉ SALDAÑA

TRANSLATED BY BERNABÉ MADRIGAL

University of Texas Press $\mathbf{r}$ Austin 
Copyright (c) 2006 by the University of Texas Press

All rights reserved

Printed in the United States of America

First edition, 2006

Originally published as Historia social de las ciencias en América Latina

(C) UNAM and M. A. Porrúa, Librero-Editor, Mexico City, 1996

Requests for permission to reproduce material from this work should be sent to:

Permissions

University of Texas Press

P.O. Box 7819

Austin, TX 78713-7819

www.utexas.edu/utpress/about/bpermission.html

@ The paper used in this book meets the minimum requirements of ANSI/NISO Z39.48-1992 (R1997) (Permanence of Paper).

\section{Library of Congress Cataloging-in-Publication Data}

Historia social de las ciencias en América Latina. English.

Science in Latin America : a history/edited by Juan José Saldaña ; translated by Bernabé Madrigal.- 1 st ed.

$$
\text { p. } \mathrm{cm} \text {. }
$$

Includes bibliographical references

ISBN-13: 978-0-292-71271-3 (alk. paper)

ISBN-10: 0-292-71271-5 (alk. paper)

1. Science-Latin America-History. 2. Science-Social aspects-Latin America.

I. Saldaña, Juan José. II. Title.

Q127.L38H57813 2006

$509.8-\mathrm{dc} 22$

2005035364 